\title{
College Libraries and International Understanding
}

$I^{2}$

T Is SURPRISING to see how little space 1 has been given in recent professional literature to the question as to how college libraries can promote international understanding in a new era. ${ }^{2}$ At the end of the long war emergency many college librarians seem to be preoccupied with more immediately pressing problems: they are busy fighting for better budgets, improving their often disheartening personnel situation, or planning for a more adequate new library building. But, in the understandable urge of returning to normalcy, librarians should not overlook the fundamental issues of their time and should offer their modest contribution toward solving them.

This conviction is based on the writings of two great scholar-librarians of this century, the German, Adolf von Harnack, and the American, William Warner Bishop. The former director-general of the Prussian State Library drew the lessons of a unique career in a wise paper which he wrote in the turbulent period following the First World War. "The spirit of universal enlightenment should preside over the library," Harnack stated there. "No librarian ought ever

1 This paper was read at the meeting of the College Libraries Section of the A.C.R.L. at Chicago, Dec. 28,

${ }_{2}^{1945}$ The three most significant comments on the subject are to be found in the annual report of the librarian of Wellesley College, September I944, in the annual report of 1942-43 of the librarian of Colgate University (partly reprinted in School and Society 59:268-69, Apr. 15, 1944), and in the paper by Robert McEwen, "American College Libraries in the Postwar Era", (College and Research Libraries 3: p. 293, September I942).

${ }_{3}^{2}$ Zentralblatt für Bibliothekswesen 40: 529-37, 1923. The gist of this paper is given in translation in the present author's essay on "The Scholar as Librarian." ('Library Quarterly 9: 299-320, July I 939.) to forget that his building must be an asylum of peace." The more the great libraries, he goes on to say, are treasured and used as the common property of mankind, the more will they contribute toward a reunion of the divided civilized world. "Bibliotheca docet!" Four years ago, at the midwinter meeting of the American Library Association in December 194I, Bishop expressed himself in a similar spirit and warned his fellow librarians against the evils of propaganda." "It is distinctly up to the librarians," he said, "to resist hysteria, to acquire the printed sources of knowledge from all countries, and to foster that intercourse of minds which alone develops understanding." He concluded that every effort made in each individual library for a better appreciation of the culture of other peoples, every formal attempt at international cooperation, every personal gesture of friendship, counts in the great cause of freedom.

\section{An Inescapable Duty}

If Bishop was right, at the beginning of the Second World War when passion ran high, how much more strength can be derived from his noble words now that the crisis has passed and the cause of freedom has prevailed. The year 1945 witnessed the disaster of the Axis countries, but the world is yet far, far away from true peace. College librarians have the inescapable duty to do their bit in order that the young people

" "Libraries in the International Picture." A.L.A. Bulletin 36: I 2-13, January 1942. 
who are now engaged in academic studies may live and study in real peace. Within the natural limits set to the librarian's work, he should make the college students aware of the job ahead and of the dangers to be faced. He and his staff should offer them every opportunity to investigate the implications of the atomic bomb, the potentialities of the United Nations Organization, the question of the reconstruction of Europe and the Far East and of the American stake in it. In particular, he should present them with well-rounded, up-to-date, and absolutely fair pictures of foreign countries and leave it to the reader to draw whatever conclusions he deems justified. The college librarian does not interfere with the rightful functions of the teaching faculty if he, on his own initiative, spreads the best available information before the young generation. On the contrary, he merely supplements and supports the efforts of professors in various branches of knowledge-geography as well as physics, history and sociology, economics, and foreign languages. He fills the gaps they are bound to leave in any college curriculum; he coordinates activities and stimulates thought in his humble ways. Never should the college librarian push himself into the foreground; instead, he may have the deeper satisfaction that the reputation of his library will grow if it is able to serve as an effective agent of international understanding on campus. Successful work in this direction is not a privilege of the heavily endowed institutions. This paper, on the contrary, aims to demonstrate how much a college library may achieve with an annual appropriation of less than five thousand dollars for books and periodicals if the library staff shows the right spirit and builds up the collection intelligently and systematically.

\section{More Foreign Encyclopedias}

The reflections should start from a critical survey of the collection, for the best spirit will not lead the librarian far, if he lacks the indispensable tools. The reference collection, of course, deserves first attention. Most college libraries will have to add to their holdings of foreign encyclopedias. This is a rather expensive proposition, but Britannica and Americana simply won't do the job. This writer is obligated to state, from his experience as chairman of the area training program for the A.S.T.P. language and area unit at Bard College, ${ }^{5}$ that the instructors would never have been able to give their soldier students an adequate idea of Central and Western Europe, had it not been for Der Grosse Brockhaus and La Grande Encyclopédie with their unrivaled wealth of detailed information. The latter set should be supplemented by Larousse $d u$ $X X^{\text {ème }}$ Siècle which will soon be imported again from France; the former will be indirectly kept up to date by the Schweizer Lexikon which Swiss scholars prepared during the war and whose first volume is about to reach the shores of this country. High on the list of desiderata for college libraries is also the Enciclopedia Italiana, even though there may be linguistic handicaps for its extensive use. In many respects, this is the best product of modern European encyclopedia-making and therefore should be accessible to qualified readers. The purchase of the costly set of Enciclopedia Universal Ilustrada Europeo-Americana will be advisable in any college stressing the study of Hispanic civilization. Wherever possible, college libraries should also acquire outstanding subject encyclopedias in foreign languages, e.g., Handwörterbuch der Staatswissenschaften and Propyläen-Weltgeschichte will help considerably to improve reference work in the social sciences.

There is a pressing need to streamline the

\footnotetext{
$\checkmark$ This experience is described more fully in his article, "Soldiers Study Foreign Areas." Wilson $\mathrm{Li}$ brary Bulletin 18: 599-603, April 1944.
} 
collection of foreign language dictionaries. It would be a poor college library which did not have on its shelves the major dictionaries in Russian, Polish, Portuguese, Dutch, Chinese, and Japanese, regardless of whether or not there are courses in these languages offered on campus. College libraries should be ready to face any emergency; the reader who wants urgently to get at the meaning of some pamphlet or periodical article from abroad should not have to wait till the librarian might condescend to order the needed dictionary from his bookseller. All these dictionaries are today within reach of the smaller college library. The same holds true for most of the international statistical handbooks and various yearbooks; it should be made a practice to have the major publications of such organizations as the League of Nations and the International Labour Office available in their latest editions. There is also frequent demand for biographical information as provided in the more important foreign who's whos. The bibliographical coverage of international problems, too, deserves attention; the two indispensable volumes of the Foreign Affairs Bibliography should be supplemented by such handy tools as Philip Grierson's Books on Soviet Russia, I9I7-1942. Finally, there is need for more and better atlases. No college library should be satisfied before having acquired the major European atlases. They surpass their American counterparts as far as solid geographical information on the Old World is concerned, as anybody will admit who has ever examined the jubilee edition of Stieler's Atlas of Modern Geography and the Great Soviet World Atlas.

\section{Imperative Periodicals}

The next job is a thorough overhauling of the periodicals collection; this is a very exacting and time-consuming task. The smaller college library cannot subscribe cur- rently to all important foreign periodicals nor acquire innumerable costly sets. Therefore a well-balanced cross section must be aimed at which will provide for a wide range of solid and readable information. The list given below should satisfy a great variety of demands. In all cases current subscription should be accompanied by the purchase of reasonably extensive backfiles, e.g., the set of the London Economist, which was gradually expanded back to I924, has certainly been a tremendous help to many Bard students in search of knowledge on world affairs. The list does not include American general magazines like Atlantic Monthly, Harper's, Nation, New Republic, Yale Review, etc., which are available everywhere, nor those learned periodicals such as The Annals of the American Academy of Political and Social Sciences, Economic Journal, London, Political Science Quarter$l y$, and Public Opinion Quarterly, which do not regularly contain information on foreign countries, even though they often print outstanding articles on international affairs. Here are the twenty-five indispensable titles:

\section{American Review on the Soviet Union Asia and the Americas \\ Books Abroad \\ Christian Century \\ Commonweal}

Contemporary Review, London

Current History

Economic Geography

Economist, London

Foreign Affairs

Foreign Policy Reports and Bulletin

Free $W$ orld

Geographical Review

Hispanic American Historical Review

International Affairs, London

International Labour Review

Journal of Central European Affairs

Journal of Modern History

National Geographic Magazine

New Statesman and Nation, London

Nouvelles Littéraires, Paris

Pacific Affairs 
Pan American Union Bulletin

Social Research

Soviet Russia Today

The new International Journal, whose first issue (Winter 1946) has just been announced by the Canadian Institute of International Affairs, and any worthy successor to the Revue des Deux Mondes that will be established in Paris, may have to be included eventually. To the twenty-five titles should be added France Illustration, Paris, and The Illustrated London News which provide often needed pictorial information in exemplary fashion; Norte, New York, though less distinguished than these two magazines, is also highly desirable. A check in the revised edition of the Union List of Serials and its first supplement shows that many of these titles are missing in hundreds of respectable academic libraries.

In addition, college librarians should turn to an inexpensive and most rewarding tool of international understanding: the foreign language newspapers. If they want to let students know what is going on in vanquished Germany, Aufbau and Neue Volkszeitung in New York will be gold mines. A subscription to the lively Swiss weekly paper Die Weltwoche, Zurich, will also be profitable, since it approaches the whole complex of Central European problems with fairness. French questions are ably discussed in France-Amérique and La Victoire, New York. The'Saturday editions of Le Jour and La Presse, Montreal, add the French-Canadian flavor. The crisis of the British Empire is mirrored in London Times Weekly and Manchester Guardian Weekly. The daily paper La Prensa, New York, and the Sunday editions of $\mathrm{La}$ Nacion and $\mathrm{La}$ Prensa, Buenos Aires, will help toward understanding Spanish and Latin American troubles. It goes without saying that every college library should subscribe to New York Times (with index), Christian Science
Monitor, and-either New York Herald Tribune or Chicago Daily News, because their coverage of world events is superior to that of all other American papers.

\section{Improve Geography Collections}

For no good reason, geography is treated in many colleges as a minor subject which is taught occasionally only. Therefore, the book collections in this field tend to be very uneven. Often outmoded travelogs of merely historical relevance predominate. But it is important that the library make available to the students timely books of scholarly merit on literally. every country/ The good college librarian will not wait with his acquisitions till trouble may again be brewing in Yugoslavia, Poland, Iran, Korea, Palestine, or the Dutch East Indies, but will have up-to-the-minute information of superior quality on the shelves ready for the next emergency. In addition, there ought to be built up by the librarian (if no professor claims the privilege) a geographichistorical collection for every major area of the world sufficient to present the basic aspects of its civilization. To give but one example: a student who becomes interested in the problems of South Africa should find in his college library not only such recent manuals of African geography as those by Walter Fitzgerald and Carveth Wells, some of the more appealing modern travel books, and the two or three best biographies of Cecil John Rhodes and Jan Christian Smuts, but also Lord Malcolm Hailey's monumental African Survey, volume eight (South Africa) of the Cambridge History of the British Empire, and C. W. De Kiewiet, History of South Africa, Social and Economic, to mention only three outstanding titles. First-rate pictorial material as contained in Richard Upjohn Light's Focus on Africa will also help considerably. Wherever possible, sociological interpretations of 
foreign countries should be on hand: Mouch'un Yang's recent fascinating study of $A$ Chinese Village and John F. Embree's Suye Mura, A Japanese Village, would be representative of this important group of interpretations.

College students who neither traveled abroad nor served in the armed forces overseas, do not always readily understand the value of becoming proficient in foreign languages. They are bored by the only too harmless tidbits of French, Spanish, or German literature which they find inevitably in their elementary textbooks. They will appreciate the greatness of other civilizations more easily if they see masterpieces of foreign thinkers and scientists interspersed in the subject collections of their college library. The student who comes across the original works of Croce, Maritain, Ortega y Gasset, Madariaga, Albert Schweitzer, or Einstein, and finds out that he can struggle through part of the text, will be overjoyed by such real accomplishment. There should be surprises of this kind ready for him in various corners of the building, even though the library cannot attempt to buy original editions of all important foreign scholars.

Another field in which the college librarian can show his initiative is the development of skeleton collections in those languages which do not yet appear in the college catalog. The slow-moving curriculum makers on many a campus have not yet understood that Russian is a coming major language. But there are students around who have more vision than their elders and who would like to get started as soon as possible. The librarian certainly should provide for these pioneers, and three or five years hence the faculty will be grateful to him for not having waited until the new Russian department has seen the light of day at last. The enterprising college li- brarian, who is willing to sacrifice fifty or sixty dollars for the purpose, will be able to acquire a dozen elementary and intermediate language readers of varying approach-The Oxford Book of Russian Verse, Pushkin's The Captain's Daughter, the new bilingual series of important texts published by Harrap and Transatlantic Arts, and some other basic items which will satisfy the curiosity of the beginner.

Efforts should be made to attract students who are lacking in linguistic talents, by spreading out before them a galaxy of the writings of significant foreign authors in translation. There will be less feeling of superficiality regarding the Good Neighbor policy, if students approach history and present-day problems of Latin America through such literary media as Ciro Alegria's Broad and Alien Is the World, Mariano Azuela's The Under Dogs, Euclydes da Cunha's Rebellion in the Backlands, J. J. Fernández de Lizardi's The Itching Parrot, Rómulo Gallegos' Doña Bárbara, Ricardo Güiraldes' Don Segundo Sombra, and the collected stories Fiesta in November (edited by Flores and Poore). A good cross section of literature in translation is particularly desirable when few people, if any, on campus can read the original (say in Norwegian or Czech). Also it should not be beneath the dignity of a college library to possess collections of foreign fairy tales. Few books reveal more about certain features in the respective national characters than do the recent magnificent Pantheon editions of Grimm's Fairy Tales and the Russian Fairy Tales.

\section{Audio-Visual Aids}

The interpretation of foreign civilizations can be greatly enlivened by the proper use of audio-visual materials. It is within the province of the librarian to coordinate and develop the map collections on the campus, 
unless the geography department shows the necessary leadership. There should be a diversified and up-to-date collection of firstrate wall maps on all major regions of the world readily available in every American college. Good pictures can also aid in the appreciation of other countries. The library should aim at providing fine reproductions of the landmarks of architecture and other characteristic masterpieces of the arts. Educational and documentary films and outstanding slide material on foreign topics are also well worth having, if there is a projector in the library or elsewhere on campus. Lastly, the librarian and his staff ought to build up a collection of choice records which will bring the widest range of great foreign music and literature to interested students at leisurely gatherings.

Pamphlets of foreign origin form a tool of information which is not yet sufficiently evaluated in many college libraries. The reference department should see to it that there is a constant influx of this inexpensive material. The intelligent reader will immediately sense the bias, if a publication represents merely foreign propaganda tendencies, and will, nevertheless, be glad to have a chance to examine it because he can then weigh the evidence for himself. Among agencies giving free pamphlet material in quantities to libraries, the Woodrow Wilson Foundation, New York City, which has done pioneering work for international cooperation, is prominent. Also, such pertinent official documents as the reports of U.N.R.R.A. and the hearings of the Senate committee on atomic energy (which are now at the printer's) should be displayed in the library.

\section{Wider Knowledge of Languages}

Turning from the collections to the personal side of the problem, it must be admitted that many college librarians and their reference assistants are not yet fully prepared for the job ahead. If librarians are to be informal agents of international understanding, they should first see to it that the newcomers to the profession have an adequate foundation on which to build. That includes, above all, a much more thorough familiarity with foreign languages. The traditional "reading knowledge," usually a very shaky affair, will not do any longer. There is need for more staff members who can peruse and interpret with ease complex texts in French, German, Italian, Portuguese, Russian, and Spanish, for the benefit of the whole college community,

Among the candidates for the profession there ought to be a much larger percentage of those who majored in college in one of the social sciences, be it geography, history, economics, or government. As library assistants they should be able to open up effectively the materials relating to world affairs.

\section{Study and Travel Abroad}

Now that travel abroad will soon be possible again, enthusiastic young members of the profession who are looking forward to college library work as a career should receive every encouragement in their efforts to see parts of the world. Funds ought to be solicited at once from government agencies and private foundations which would enable qualified prospective librarians to undertake carefully planned journeys to specific areas (no Cook's tours!) or to study at leading foreign universities for a semester or a year. Also, effective methods should be devised for making possible an exchange of assistants with comparable scholarly libraries abroad.

While it seems fairly easy to offer prescriptions to the neophyte, it is much harder to put into a few words what the college librarian himself ought to do for his self- 
improvement. His foremost obligation is to read much more widely and more deeply on world affairs. He can offer real guidance to young people and undertake expert book selection only if he knows far more than yesterday's headlines about the outside world. Of course, no librarian could be an authority on everything, but it seems to be the noblesse oblige of his profession that, if necessary, its members are capable of taking leadership on campus in this most crucial field. As a matter of course, every librarian ought to cooperate closely with all faculty members interested in international affairs, ask for their advice, and assist them in every way possible. He should help in coordinating their efforts, as was suggested at the beginning. Also, he should keep in constant contact with any student group endeavoring to explore the world situation. On many a campus such organizations will give the most active support in building up and advertising this part of the library collection.

\section{Usefulness of Exhibits}

There is nothing as constructive as this informal day-by-day effort of the librarian and his staff. However, there are also a few additional avenues of approach. The librarian can promote international understanding, e.g., by preparing highly selective bibliographies on timely topics and especially on the major countries of the world. He will be the more successful with distributing such lists, the more he concentrates on books that live and the more he masters the fine art of annotation. A bibliography which is just repeating what may be easily be found in the card catalog under one heading or two, is not worth the paper it is printed or mimeographed on. There is also some virtue in having simple displays in various strategic corners of the campus; they may focus attention on the wealth of information that the library has on some current international problem.

In wartime it was often hard to arrange for larger exhibitions on foreign subjects, since the risks of transporting rare items were prohibitive. Nevertheless, many college libraries succeeded in having instructive showings of their own treasures from time to time. But with the return to normalcy librarians may try to put the huge display cases again to fuller use, hoping (though not always being certain) that the heavy investment of time and energy in preparing elaborate exhibitions may pay some dividend in form of enthusiasm aroused and knowledge promoted. There are some international agencies that may be expected to be helpful to college libraries in this respect. The British Library of Information, Books Across the Sea, the former Office of the Coordinator of Inter-American Affairs, representatives of various foreign governments, and certain travel agencies which cannot be enumerated here, were approached with good success on many occasions. However, in spite of all outside assistance, any large exhibit will remain a challenge to the librarian. He should rely more on his own ingenuity and industry than on the kindness of others. But he may be well-advised to have the exhibition opened by a talk of a forceful and attractive speaker, perhaps a widely-known foreign expert.

All these activities may contribute toward creating the right spirit, which should be the librarian's main concern. At the beginning, the judicious remarks of Harnack and Bishop were quoted in order to describe this general attitude. In summing up, may the wish be expressed that the words which stand over the entrance of International House, New York City, could be placed in invisible letters also above the doors of all American college libraries: "That brotherhood may prevail." 